\title{
KEEFEKTIFAN MODEL PEMBELAJARAN SNOWBALL THROWING BERBANTU MEDIA PUZZLE TERHADAP HASIL BELAJAR
}

\author{
Jevri Nugroho Setianto ${ }^{1}$, Rahmat Rais ${ }^{2}$, Khusnul Fajriyah ${ }^{3}$ \\ ${ }^{1,2,3}$ Pendidikan Guru Sekolah Dasar, Fakultas IImu Pendidikan,Universitas PGRI Semarang \\ e-mail: jevrins@gmail.com
}

\begin{abstract}
ABSTRAK
Peneliti ini bertujuan untuk mengetahui adanya keefektifan untuk meningkatkan hasil belajar atau tidaknya model pembelajaran Snowball Throwing dengan media Puzzle. Penelitian ini merupakan penelitian pre-experimental jenis kuantitatif. Penelitian ini menggunakan one-group pretest-posttest design. Populasi dalam penelitian ini adalah seluruh peserta didik kelas IV SD Negeri Ketitangwetan 02 berjumlah 20 siswa tahun ajaran 2019/2020. Intrumen yang digunakan adalah wawancara, dokumentasi dan tes. Analisis Data menggunakan Teknis analisis data peneliti menggunakan uji normalitas dan (uji-t). Uji normalitas digunakan untuk mengetahui kelas tersebut berdistribusi normal atau tidak. Uji t-test digunakan untuk mengetahui perbedaan hasil belajar. Hasil penelitian yang dilakukan dapat disimpulkan bahwa model pembelajaran Hasil penelitian dapat disimpulkan bahwa model pemeblajaran Snowball Throwing dengan media Puzzle dapat meningkatkan hasil belajar siswa kelas IV tema 2 subtema 2 pembelajaran 1-3. Hal ini dapat dilihat Hal tersebut dilihat dari hasil perhitungan uji-t dengan taraf signifikan $=5 \%$ Dengan menggunakan uji-t satu pihak didapatkan nilai 1,68595. Dari perhitungan diatas diperoleh sebesar 6,242283. Maka hasilnya > yaitu 6,242283 >1,68595. Dengan demikian $H O$ ditolak dan $H a$ diterima. Artinya model pembelajaran snowball throwing dengan media puzzle efektif terhadap hasil belajar.
\end{abstract}

Kata Kunci : Model Pembelajaran Snowball Throwing, Media Puzzle, Hasil Belajar

\begin{abstract}
This researcher aims to determine the effectiveness to improve learning outcomes or not the learning model of Snowball Throwing with Puzzle media. This research is a quantitative type preexperimental research. This study uses a one-group pretest-posttest design. The population in this study were all grade IV students of SD Negeri Ketitangwetan 02 totaling 20 students in the 2019/2020 school year. The instruments used were interviews, documentation and tests. Data analysis using the technical data analysis researchers used the test for normality and (t-test). Normality test is used to determine whether the class has a normal distribution or not. T-test is used to determine differences in learning outcomes. The results of the study conducted can be concluded that the learning model The results of the study can be concluded that the learning model of Snowball Throwing with Puzzle media can improve student learning outcomes in class IV theme 2 subtema 2 learning 1-3. This can be seen It is seen from the results of $t$-test calculations with a significant level $=5 \%$ By using one-party $t$-test obtained a value of 1.68595. From the above calculation, the $t$ count is 6.242283 . Then the result is t_count> t_table which is 6.242283> 1.68595. Thus HO is rejected and Ha is accepted. This means that the snowball throwing learning model with puzzle media is effective on learning outcomes
\end{abstract}

Keywords : Snowball Throwing learning model, Media Puzzle, Learning Outcomes, 


\section{Pendahuluan}

Pendidikan adalah usaha sadar dan terencana untuk mewujudkan suasana belajar dan proses pembelajaran agar peserta didik secara aktif mengembangkan potensi dirinya untuk memiliki spiritual keagamaan, pengendalian diri, kepribadian, kecerdasan, akhlak mulia, serta ketrampilan yang diperlukan dirinya dan masyarakat. Hal tersebut untuk menghadapi tantangan dimasa sekarang ini maupun dimasa depan. Sebagaimana yang didefinisikan dalam Undang-Undang No. 20 Tahun 2003 pasal 1 tentang Sistem Pendidikan Nasional menyebutkan bahwa pendidikan adalah usaha sadar dan terencana untuk mewujudkan suasana belajar dan proses pembelajaran agar peserta didik secara aktif mengembangkan potensi dirinya untuk memiliki kekuatan spiritual keagamaan, pengendalian diri, kepribadian, kecerdasan, akhlak mulia, serta keterampilan yang diperlukan dirinya, masyarakat, bangsa dan negara.

Pelaksanaan pendidikan di Indonesia diatur suatu kurikulum. Undang-undang No. 20 Tahun 2003 pasal 1 tentang Sistem Pendidikan Nasional menyebutkan bahwa kurikulum adalah seperangkat rencana dan peraturan mengenai tujuan, isi, dan bahan pelajaran serta cara yang digunakan sebagai pedoman penyelenggaraan kegiatan pembelajaran. Untuk mencapai tujuan pendidikan tertentu. Peraturan Menteri Pendidikan dan Kebudayaan Nomer 67 Tahun 2013 tentang kerangka dasar dan struktur kurikulum Sekolah Dasar/Madrasah Ibtidaiyah. Struktur kurikulum dikembangkan menjadi empat kompetensi inti yaitu KI 1 (sikap spiritual), KI 2 (sikap social), KI 3 (pengetahuan), KI 4 (ketrampilan). Terkait dengan pelaksanaan pendidikan di Indonesia pemerintah berupaya untuk meningkatkan kualitas pendidikan secara menyeluruh, misalnya dengan meningkatkan kualitas pendidikan melalui pembelajaran. Di dalah pembelajaran pasti ada proses pembelajaran, proses pembelajaran harus berlangsung dengan baik apabila ingin mendapatkan hasil yang baik. Salah satu yang mempengaruhi proses pembelajaran adalah guru, guru harus inovatif dalam proses pembelajaran sehingga pembelajaran cenderung tidak membosankan dan menjadikan siswa aktif dalam pembelajaran.

Keberhasilan dalam proses pembelajaran tidak terlepas dari kemampuan guru dalam mengembangkan model-model pembelajaran. Pengembangan model pembelajaran yang bertujuan untuk menciptakan siswa yang aktif dalam proses pembelajaran sehingga siswa meraih hasil belajar yang optimal.

Selain model pembelajaran yang dapat membantu dalam keberhasilan pembelajaran adalah media pembelajaran. Media pembelajaran berperan penting dalam proses pembelajaran karena dengan adanya media pembelajaran guru lebih mudah dalam menyampaikan materi dan siswa lebih aktif untuk berdiskusi dan memperhatikan apa yang disampaiakan oleh guru. Peran media tidak hanya sebagai alat bantu menyampaikan materi tetapi diharapkan mampu merangsang siswa untuk lebih mendalami atau memahami isi materi yang lebih jauh.

Hasil wawancara dengan guru kelas IV SD Negeri Ketitangwetan 02 Ibu Susmiyati S.Pd. Dalam proses pembelajaran guru hanya menggunakan metode ceramah dan tidak menggunakan medel pembelajaran sehingga tidak menarik perhatian siswa dalam proses pembelajaran. Permasalahan tersebut menyebabkan hasil belajar siswa yang masih rendah yakni dibawah KKM 70.

Tabel 1. Data nilai ulangan harian siswa kelas IV SD Negeri Ketitangwetan 02 tema 1.

\begin{tabular}{cccc}
\hline Kelas & Jumlah Siswa & Tuntas & Tidak Tuntas \\
\hline IV & 20 & 9 Anak & 11 Anak \\
\hline
\end{tabular}

Upaya mengenai permasalahan diatas adalah dengan mengguanakan model pembelajaran dan juga media pembelajaran dengan menggunakan model pembelajaran snowball throwing untuk meningkatkan hasil belajar siswa. Model pembelajaran ini sangat tepat untuk diterapkan pada siswa sekolah dasar, karena model ini membuat siswa lebih aktif sehingga hasil belajar siswa meningkat. Menurut Yuliati (2015) Metode Snowball 
Throwing merupakan salah satu model pembelajaran kooperatif. Metode pembelajaran tersebut mengandung unsur-unsur pembelajaran kooperatif. Snowball artinya bola salju sedangkan throwing artinya melempar. Snowball Throwing dapat diartikan sebagai metode pembelajaran yang menggunakan bola pertanyaan dari kertas yang digulung bulat berbentuk bola kemudian dilemparkan secara bergiliran di antara sesama anggota kelompok. Snowball throwing yaitu metode pembelajaran yang didalam terdapat unsur-unsur pembelajaran kooperatif sebagai upaya dalam rangka mengarahkan perhatian siswa terhadap materi yang disampaikan oleh guru. Model pembelajaran kooperatatif Snowball throwing merupakan salah satu dari sekian banyak tipe pembelajaran kooperatif. Model pembelajaran kooperatif tipe Snowball thowring ini selalu diawali dengan membagi kelas menjadi beberapa kelompok, dimana setiap kolompok memiliki satu orang ketua yang akan mewakili teman sekelompoknya untuk mendengarkan penjelasan dari guru tentang materi yang akan di pelaJari. Setiap siswadi berikan kesempatan untuk menuliskan pertanyaan di selembar kertas mengenai hal-hal yang kurang atau belum mereka pahami guna membentuk pola pikir yang mandiri bagi setiap siswa. Menurut Huda (2013 : 226) Model pembelajaran kooperatif tipe Snowball Throwing adalah suatu model pembelajaran yang diawali dengan pembentuka kelompok yang diwakili ketua kelompok untuk mendapat tugas dari guru kemudian masingmasing siswa membuat pertanyaan yang dibentuk seperti bola (kertas pertanyaan) lalu dilempar ke siswa lain yang masing-masing siswa menjawab pertanyaan dari bola yang diperoleh. Menurut Rosida (2017) Model pembelajaran kooperatif tipe Snowball Throwing dapat menigkatkan aktivitas dan kreatifitas siswa, melatih siswa belajar mandiri dalam pengetahuan berdasarkan diskusi, mengembangkan kemampuan berpikir siswa dalam mendiskusikan dan meyelesaikan tugas belajar, mengembangkan kemampuan mengemukakan pendapat, meningkatkan kemampuan menjelaskan kembali materi yang diperoleh berdasarkan diskusi, dan meningkatkan hasil belajar siswa. Menurut Hamid (2012: 230) Snowball Throwing merupakan metode pengembangan model kooperatif. Snowball Throwing adalah suatu permainan melempar bola salju sebagai salah satu strategi pembelajaran yang dapat merangsang siswa untuk mengajukan pertanyaan dan menjawab pertanyaan.

Media yang tepat untuk mengenai masalah tersebut yaitu media puzzle. Menurut Yudha (dalam Rosiana Khomsoh 2013:2) Puzzle adalah suatu gambar yang dibagi menjadi potongan-potongan gambar yang bertujuan untuk mengasah daya piker, melatih kesabaran, dan membiasakan kemampuan berbagi. Selain itu, media puzzle juga dapat disebut permainan edukasi karena tidak hanya untuk bermain tetapi juga mengasah otak dan tangan. Oleh karena itu puzzle diharapkan dapat meningkatkan hasil belajar siswa. Menurut Rumakhit (2017) Media puzzle merupakan media pembelajaran yangsifatnya memberikan rasa nyaman berfikir melalui permainan dimaksudkan agar dalam kegiatan pembelajaran lebih menarik dan siswa lebih tertarik. Media puzzle dapat dikembangkan menjadi media tiga dimensi agar siswa lebih tertarik untuk belajar sambil bermain pada saat proses belajarsehingga siswa mampumengidentifikasi beberapa jenis hubungan simbiosis dan rantai makanan dengan tepat. Cara kerja puzzle dalam pembelajaran dengan membagi siswa menjadi beberapa kelompok yang terdiri dari 3-4 siswa. Setiap kelompok menyelesaikan tugas masing-masing puzzle yang diberikan. Menurut Nisak (2011: 110) permainan puzzle ini memiliki tujuan sebagai berikut: a) membentuk jiwa bekerjasama pada peserta, karena permainan ini aklan dikerjakan secara berkelompok. b) peserta dapat lebih konsisten dengan apa yang sedang dikerjakan. c) melatih kecerdasan logis matematis peserta. d) menumbuhkan rasa solidaritas sesama siswa. e) menumbuhkan rasa kekeluargaan antarsiswa. f) melatih strategi dalam bekerjasama antarsiswa. g) menumbuhkan rasa saling menghormati dan menghargai antarsiswa. $h$ ) menumbuhkan rasa saling memiliki antarsiswa. i) menghibur para siswa di dalam kelas. Menurut Suciaty (2010: 78) manfaat dari permainan ini sebagai berikut: 1) Mengasah otak. Puzzle adalah cara yang bagus untuk mengasah otak si kecil, melatih sel-sel saraf, dan memecahkan masalah. 2) Melatih koordinasi mata dan tangan. Puzzle dapat melatih koordinasi tangan dan mata anak. Mereka harus mencocokkan keepingkeping puzzle dan menyusunnya menjadi satu gambar. Permainan ini membantu anak mengenal bentuk dan merupakan langkah penting menuju 
pengembangan keterampilan membaca. 3) Melatih nalar. Puzzle dalam bentuk manusia akan melatih nalar mereka. Mereka akan menyimpulkan dimana letak kepala, tangan, kaki dan lain-lain sesuai dengan logika. 4) Melatih kesabaran. Puzzle juga dapat melatih kesabaran anak dalam menyelesaikan suatu tantangan. 4) Pengetahuan. Dari puzzle anak akan belajar. Misalnya, puzzle tentang warna dan bentuk maka anak dapat belajar tentang warna-warna dan bentuk yang ada. Pengetahuan yang diperoleh dari cara ini biasanya lebih mengesankan bagi anak dibanding dengan pengetahuan yang dihafalkan. Anak juga dapat belajar konsep dasar, binatang, alam sekitar, jenis buah, alphabet, dan lain-lain. Tetapi dalam permainan ini tentunya harus dengan bantuan ibu atau orang lain yang dapat mendampinginya.

Berdasarkan latar belakang masalah yang telah dikemukakan diatas, dapat mengidentifikasi masalah sebagai berikut : 1) Metode pembelajaran masih menggunakan metode ceramah atau proses pembelajaran masih berpusat pada guru sehingga siswa kurang aktif dalam kegiatan pembelajaran.2) Rendahnya hasil belajar yang dicapai siswa kelas IV yang dilihat dari data nilai pengetahuan masih ada yang dibawah KKM 70. 3) Tidak adanya media pembelajaran yang mendukung dalam pembelajaran.

\section{Metode}

Metode penelitian pada dasarnya merupakan cara ilmiah untuk mendapatkan data dengan tujuan dan kegunaan tertentu. Berdasarkan hal tersebut terdapat empat kata kunci yang perlu diperhatikan yaitu, cara ilmiah, data tujuan, dan kegunaan (Sugiyono, 2016: 3).

Sugiyono (2017:109) metode yang digunakan dalam penelitian ini yaitu preexperimental designs. Dikatakan pre-experimental designs, karena desain ini belum merupakan eksperimen sungguh-sungguh. Karena masih terdapat variabel luar yang berpengaruh terdapat terbentuknya variabel dependen. Jadi hasil eksperimen yang merupakan variabel dependen itu bukan semata-mata dipengaruhi oleh variabel independen. Hal ini dapat terjadi, karena tidak adanya variabel kontrol, dan sampel tidak terpilih secara random.

Dari uraian metode diatas, maka penulis menggunakan desain penelitian one-group pretest-posttest design. Desain ini dapat digambarkan seperti berikut:

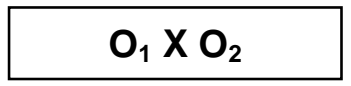

Sugiono $(2017: 111)$

$\mathrm{O}_{1}=$ nilai pretest (sebelum diberi diklat)

$\mathrm{O}_{2}=$ nilai posttest (setelah diberi diklat)

Berdasarkan desain penelitian diatas, terdapat satu kelas yang akan diberikan soal pre-test pada awal pembelajaran atau dilaksanakan sebelum kegiatan pembelajaran. Setelah diberikan pre-test siswa diberi perlakuan yaitu model pembelajaran snowball throwing. Selanjutnya pada akhir pembelajaran siswa diberikan soal post-test. Dengan pemberian pre-test dan post-test akan diketahui apakah model snowball throwing efektif terhadap hasil belajar siswa kelas IV SD Negeri Ketitangwetan 02 Batangan.

\section{Hasil dan Pembahasan}

Penelitian dilakukan di SD Negeri Ketitangwetan 02 pada semester gasal tahun ajaran 2019/2020 pada kelas IV dengan jumlah 20 siswa. Kelas IV sebagai kelas yang dilakukan model pembelajaran Snowball Throwing dengan media Puzzle pada tema 2 subtema 2 pembelajaran 1-3. Penelitian dilaksanakan selama 1 tahun. Sebelum dilaksanakan penelitian, penulis melakukan uji coba soal yang dilakukan di SD Negeri ketitangwetan 01. Instrumen dalam penelitian ini berupa soal pilihan ganda sebanyak 30 butir soal yang diuji cobakan di kelas IV. 
Dengan jumlah siswa sebanyak 20 siswa. Setelah dilaksanakan uji coba, kemudian dilakukan analisis data berupa uji validitas, reliabilitas, tingkat kesukaran dan daya pembeda. Hasil analisis diperoleh 20 soal yang digunakan sebagai soal posttest. Selanjutnya yaitu melengkapi perangkat pembelajaran yang akan digunakan untuk penelitian di kelas IV SD Negeri Ketitangwetan02 meliputi RPP, silabus dan media Puzzle.

Rancangan penelitian yang digunakan yaitu pre-experimental designs dengan bentuk one-group pretest-posttest. Subjek pada penelitian ini adalah kelas IV SD Negeri Ketitangwetan 02 yang terdiri dari seluruh siswa kelas kelas IV. Penelitian ini dilakukan sebanyak 3 kali pertemuan. Penulis melakukan pembelajaran sebanyak 2 kali di kelas , pertemuan awal digunakan untuk melaksanakan pretest dan pertemuan terakhir digunakan untuk melaksanakan posttest. Posttest diadakan untuk mendapatkan data berupa nilai yang digunakan untuk perbandingan hasil belajar. Perbandingan hasil belajar digunakan untuk mengetahui model pembelajaran snowball throwing dengan media puzzle efektif meningkatkan pada hasil belajar tema 2 subtema 2 pembelajaran 1-3 atau tidak efektif dibandingkan dengan pembelajaran konvensional.

Penulis menggunakan model snowball throwing karena model pembelajaran ini membuat siswa untuk belajar disertai bermain secara kelompok dengan menggunakan pertanyaan yang dibuat oleh siswa itu sendiri. Hal ini serupa dengan pendapat Aris Shoimin (2017:176) Kelebihannya sebagai berikut : Suasana pembelajaran menjadi menyenagkan karena siswa seperti bermain dengan melempar bola kertas kepada siswa lain, Siswa mendapat kesempatan untuk mengembangkan kemampuan berfikir karena diberi kesempatan untuk membuat soal dan diberikan pada siswa lain. Membuat siswa siap dengan berbagai kemungkinan karena siswa tidak tahu soal yang dibuat temannya seperti apa. Siswa terlibat aktif dalam pembelajaran. Pendidik tidak terlalu repot media karena siswa terjun langsung dalam praktik. Pembelajaran menjadi lebih efektif dan ketiga aspek kognitif, afektif, dan psikomotor dapat tercapai.

Penelitian yang peneliti lakukan selama 1 tahun dengan judul penelitian keefektifan model pembelajaran snowball throwing berbantu media puzzle terhadap hasil belajar siswa kelas IV SD Negeri Ketitangwetan 02 Batangan diperoleh hasil penghitungan uji t pada data akhir sampel, diperoleh thitung $=6,242283$. Dari daftar tabel, dengan DK pembilang $=(20$ $+20-2)=38$ dengan taraf signifikan $5 \%$ (satu pihak), maka diperoleh ttabel $=168,595$, sehingga hasil pengitungan uji t diperoleh thitung $>$ ttabel yaitu 6,242283 $>168,595$. Dengan demikian $H O$ ditolak dan $H a$ diterima. Ada perbedaan keefektifan hasil belajar antara pembelajaran yang menggunakan model pembelajaran Snowball throwing dengan model pembelajaran konvensional pada tema 2 subtema 2 pembelajaran 1-3.

Dari pembahasan di atas dapat disimpulkan bahwa pembelajaran dengan menggunakan model pembelajaran snowball throwing dengan media puzzle efektif terhadap hasil belajar siswa dari pada menggunakan metode konvensional. Rata-rata kelas IV yang menggunakan model pembelajaran snowball throwing dengan media puzzle lebih tinggi dibandingkan dengan yang menggunakan model konvensional. Rata-rata 65,75 : 73,25 dengan demikian, model pembelajaran snowball throwing dengan media puzzle efektif terhadap hasil belajar siswa kelas IV tema 2 subtema 2 SD Negeri Ketitangwetan 02 Batangan.

Peningkatan rata-rata hasil belajar antara pre-test dan post-test dapat dicapai tidak lepas dari kegiatan belejar mengajar menggunakan model pembelajaran snowball throwing berbantu media puzzle serupa dengan pendapat Ari Shoimin. Mendiskusikan tugas yang diberikan guru dengan anggota kelompok, menuliskan pertanyan sesuai dengan materi yang dijelaskan guru, menuliskan jawaban atas pertanyaan yang didapatkan dari kelompok lain.Untuk mengasah kemampuan berdiskusi, ketrampilan, kompetensi, berpikir kritis siswa dalam belajar. 


\section{Simpulan dan Saran}

Berdasarkan uraian dan analisis data dapat disimpulkan bahwa terdapat keefektifan yang signifikan model snowball throwing berbantu media puzzle terhadap hasil belajar Kelas IV SD Ketitangwetan 02 Tahun Pelajaran 2019/2020. Hal ini dapat dilihat dari rata-rata hasil belajar kelas IV yang mengalami peningkatan dan itu dibuktikan dari hasil rata-rata kelas IV yang sebelum perlakuan 65,75 dan setelah perlakuan meningkat menjadi 73,25.

Jika dilihat dari analisis uji hipotesis untuk menguji ada atau tidaknya keefektifan model pembelajaran snowball throwing dengan media puzzle efektif terhadap hasil belajar siswa kelas IV tema 2 subtema 2 pembelajaran 1-3. Hal tersebut dilihat dari hasil perhitungan uji-t dengan taraf signifikan $=5 \%$ Dengan menggunakan uji-t satu pihak didapatkan nilai sebesar Thitung $=6,242283$ dengan Ttabel $=168,595$. Karena Thitung $>T$ yaitu 6,242283 > 168,595 Dengan demikian $\mathrm{HO}$ ditolak dan $\mathrm{Ha}$ diterima. Artinya hasil belajar meningkat dengan menggunakan model pembelajaran snowball throwing dengan media puzzle pada tema 2 subtema 2 pembelajaran 1-3. Sarannya yaitu : 1) Bagi siswa dengan adanya model pembelajaran Snowball Throwing bervariasi dalam pembelajaran. Dengan model pembelajaran Snowball Throwing siswa lebih senang dan aktif karena dalam pembelajarannya siswa mengalami secara langsung pengalaman belajarnya sehingga dapat meningkatkan keefektifan hasil belajar siswa, 2) Sekolah dengan menggunakan model pembelajaran snowball throwing dengan media puzzle siswa lebih aktif dan antusias dalam mengikuti pemebelajaran, 3) peneliti selanjutnya agar dapat melalukan penelitian model pembelajaran Snowball Throwing dengan media Puzzle tidak hanya tema 2 subtema 2 pembelajaran 1-3 tetapi dalam penelitian tema yang berbeda.

\section{Daftar Pustaka}

Arikunto, Suharsimi.2010. Prosedur Penelitian. Jakarta:Rineka Cipta

Daryanto. 2014. Pembelajaran Tematik, Terpadu, Terintegrasi (Kurikulum 2013). Yogyakarta: Gava Media.

Depdiknas. 2013. Undang-Undang RI No. 20 Tahun 2003 tentang Sistem PendidikanNasional. Jakarta : Depdiknas.

Dewi, Puspa dkk. 2013. "Pengaruh Model Pembelajaran Snowball Throwing Terhadap Hasil Belajar IPA Siswa Kelas V SD Di Gugus Sri Kandi Kecamatan Denpasar Timur". EJurnal Mimbar PGSD Universitas Pendidikan Ganesha. Vol .1 No. 1 Halaman 1-10 .

Hamdani. 2011. Strategi Belajar Mengajar. Bandung: CV Pustaka Setia.

Hamid, Sholeh. 2012. Metode Edutainment. Jogjakarta: Diva Press

Huda. 2013. Model-Model Pengajaran dan Pembelajaran, Yogyakarta: Pustaka Belajar.

Huda, Miftahul. 2014. Model-Model Pengajaran dan Pembelajaran. Yogyakarta: Pustaka Pelajar.

Khomsoh, Rosiana. 2013. "Penggunaan Media Puzzle Untuk Meningkatkan Hasil Belajar Siswa Dalam Pembelajaran Ilmu Pengetahuan Sosial di Sekolah Dasar". E-Jurnal Penelitian Pendidikan Guru Sekolah Dasar. Vol .1 No. 2 Halaman 1-11.

Kusumawati, Naniek. 2017. "Pengaruh Model Pembelajaran Kooperatif dengan Snowball Throwing Terhadap Hasil Belajar IPA Pada Siswa Kelas IV SDN Bondrang Kecamatan Sawoo Kabupaten Ponorogo". E-Jurnal Kependidikan Dasar Islam Berbasis Sains. Vol .2 No. 1 Halaman 1-12. 
Muliawan, Jasa Ungguh . 2017. 45 Model Pembelajaran Spektakuler. Yogyakarta: Ar-Ruzz Media.

Nisak, Raisatun. 2011. Lebih Dari 50 Game Kreatif Untuk Aktivitas Belajar - Mengajar. Jogjakarta: Diva Press.

Peraturan Pemerintahan Republik Indonesia Nomor 65 Tahun 2013 tentang Perubahan atas Peraturan Pemerintahan Nomor 19 Tahun 2005 tentang Standart Nasional Pendidikan. http: //sindikker.dikti.go.id/. Diakses pada tanggal 23 Oktober 2016.

Rosidah, Ani. 2017. Penerapan Model Pembelajaran Kooperatif Snowball Throwing untuk Meningkatkan Hasil Belajar Siswa pada Pembelajaran IPS. Jurnal Cakrawala Pendas $\begin{array}{llllll}\text { Vol. } & 3 & \text { No.2 } & \text { Hal. } & \text { 29-36. } & \text { Tersedia }\end{array}$ http://jurnal.unma.ac.id/index.php/CP/article/view/593.

Rumakhit, Nur. 2017. Pengembangan Media Puzzle untuk Pembelajaran Materi Mengidentifikasi Beberapa Jenis Simbiosis dan Rantai Makanan Kelas IV Sekolah Dasar Tahun 2016/2017. Simki-Pedagogia Vol. 01 No. 02 Hal. 1-9. Tersedia Pada: http://simki.unpkediri.ac.id/mahasiswa/file_artikel/2017/55730c32a47f7fdf96d67740f22 3c0b2.pdf.

Rusman. 2015. Pembelajaran Tematik Terpadu Jakarta:Rajawali Pers.

Sanaky, Hujair AH. 2013. Media Pembelajaran Interaktif-Inovatif. Yogyakarta: Kaubaba Dipantara.

Siregar, Eveline dan Hartini Nara. 2014.Teori Belajar dan Pembelajaran. Bogor: Ghalia Indonesia.

Shimon, Aris.2017. 68 Model Pembelajaran Inovatif. Yogyakarta: AR Ruzz Media.

Suciaty al - azizy, A. 2010. Ragam Latiahan Khusus Asah Ketajaman Otak Anak Plus Melejitkan Daya Ingatnya. Jogjakarta: Diva Press.

Sudjana. 2005. Metoda Statistika. Bandung: PT. Tarsito.

Sugiyono. 2016. Metode Penelitian Kuantitatif, Kualitatif dan Kombinasi. Bandung: Alfabeta.

Sugiyono. 2017. Metode Penelitian Pendidikan. Bandung: Alfabeta.

Suprijono, Agus. 2017. Cooperative Learning. Yogyakarta: Pustaka Pelajar.

Susanti, Ayu dkk. 2014. "Pengaruh Model Snowball Throwing Berbantu Media Konkret Terhadap Hasil Belajar IPA Kelas V SD Gugusi Gusti Ngurah Rai Denpasar". E-Jurnal Mimbar PGSD Universitas Pendidikan Ganesha. Vol .2 No. 1 Halaman 1-10.

Suyono, Hariyanto. 2011. Belajar dan Pembelajaran Teori dan Konsep Dasar. Bandung: PT Remaja Rosdakarya.

Yuliati. 2015. Efektifitas Penggunaan Model Kooperatif Tipe Snowball Throwing untuk Meningkatkan Hasil Belajar Siswa pada Materi Sistem Pertidaksamaan Linear di Kelas XI-IS-2 SMA Negeri 7 Banda Aceh. Jurnal Peluang, Volume 3, Nomor 2, Hal. 65-78. Tersedia Pada: http://jurnal.unsyiah.ac.id/peluang/article/view/5718. 